УДК 811.111:81>276.6

ББК 81.2

DOI: https://doi.org/10.17308/lic.2020.3/2937

\title{
ПРОЦЕСС МЕТАФОРИЗАЦИИ В АНГЛОЯЗЫЧНОЙ ЮРИДИЧЕСКОЙ ТЕРМИНОЛОГИИ
}

\author{
И. А. Жилина, М. Е. Панкратова \\ Воронежский институт Министерства внутренних дел Российской Федерации
}

\author{
THE PROCESS OF METAPHORIZATION IN ENGLISH \\ LEGAL TERMINOLOGY
}

\author{
I. A. Zhilina, M. E. Pankratova \\ Voronezh Institute of the Ministry of Internal Affairs of the Russian Federation
}

\begin{abstract}
Аннотация: статья описывает процесс метафоризации англоязычных юридических терминов, рассматриваются особенности терминов-метафор. Термины с элементами метафоризации представляют собой большую трудность для перевода, так как такие понятия могут отсутствовать в языке-переводе. Объектом данного исследования является английская юридическая терминология. Материалом исследования послужил корпус примеров размером 186 терминов, полученных на основе метода сплошной выборки из словарей: Oxford dictionary of Law и Black's Law dictionary. В исследовании использован следующиий комплекс методов: системный, лингвокогнитивный, этимологический и статистический. В ходе системно-структурной обработки данных словарей были получены сведения о том, что прочесс метафоризации является полноценным и функииональным способом терминообразования в сфере юриспруденции и права. Приведены примеры терминов-метафор для различных отраслей права. Отдельно рассмотрен частеречный анализ терминов, который показывает, что большую часть метафор составляют существительные и прилагательные, единичные случаи образования терминов с помощью глаголов. Особого внимания заслуживают термины-метафоры, которые включают в себя колоративные элементы. В статье представлен анализ юридических терминов, которые содержат цветокомпоненты. Таким образом, можно сказать, что метафоризация является достаточно продуктивным способом в процессе терминообразования, но не самым частотнылм способом терминообразования. Следует помнить о том, что язык правовой терминологии не терпит многозначности, а напротив, в текстах данного типа должна быть смысловая определенность и однозначность толкования.

Ключевые слова: английская юридическая терминология, метафорический термин, колоративная образность, терминоведение.
\end{abstract}

\begin{abstract}
English-language legal terms, features of metaphor. Terms with elements of metaphorization are very difficult to translate, since such concepts may not be present in the translation language. The object of this study is English legal terminology. The material of the study was a corpus of examples of the size of 186 terms obtained using the method of continuous sampling from dictionaries: Oxford dictionary of Law and Black's Law dictionary. The following set of methods is used in the study: systemic, cognitive, etymological and statistical. During the system-structural processing of dictionary data, information was obtained that the process of metaphorization is a complete and functional way of term formation in the field of law. Examples of metaphor terms for various branches of law are given. A partial analysis of terms is considered separately, which shows that most of the metaphors are made up of nouns and adjectives, and individual cases of the formation of terms using verbs. Special attention should be paid to metaphor terms that include colour elements. The article presents an analysis of legal terms that contain color components. Thus, we can say that metaphorization is a productive way in the process of term formation, but not the most frequent way of term formation. It should be noted that the language of legal terminology does not tolerate ambiguity, but on the contrary, in texts of this type there should be certainty and unambiguity of interpretation.
\end{abstract}

Key words: English law terminology, metaphorical term, color-symbolism, terminological studies.

(C) Жилина И. А., Панкратова М. Е., 2020 


\section{Введение}

Международные деловые контакты являются неотъемлемой частью современного общества в силу развития англоязычных бизнес-коммуникаций. Исключением не стала и сфера юриспруденции, где важна не только успешность переговоров, но и точность и правильность перевода официальных и государственных документов.

В большинстве случаев сложность вызывают термины, которые отсутствуют в языке-переводе или имеют отличное от языка-оригинала значение. Еще большую сложность представляют собой термины, которые содержат в себе элементы метафоризации. В связи с этим обстоятельством мы полагаем, что процесс метафоризации англоязычной юридической терминологии является актуальным.

\section{Материалы и методы исследования}

Объектом данного исследования является английская юридическая терминология. Материалом исследования послужил корпус примеров размером 186 терминов, полученных на основе метода сплошной выборки из словарей: Oxford dictionary of Law [1] под редакцией Элизабет Мартин и Black's Law dictionary [2] под редакцией Брайана Гарнера. Словари отражают юридическую терминологию, характерную для стран англосаксонской правовой семьи, a Black's Law dictionary содержит термины, используемые в романо-германской правовой семье. В словарях приводятся как современные значения терминов, так и уже вышедшие из употребления и неиспользуемые значения терминов, что позволяет взглянуть на проблему с диахронической перспективой. Эти два издания являются достоверными, надежными и точными источниками информации. В исследовании использован следующий комплекс методов: системный, лингвокогнитивный, этимологический и статистический.

\section{Обсуждение результатов}

Терминология как наука находится в постоянном развитии, происходят случаи детерминологизации, когда одни понятия переходят в разряд общеупотребительных слов, и в то же время возникают новые понятия, которые со временем становятся терминами.

В настоящее время все еще существует проблема разграничения термина и нетермина. Для консультации обратимся к лингвистическому энциклопедическому словарю под редакцией В. Н. Ярцевой: «Термин - слово или словосочетание, обозначающее понятие специальной области знания или деятельности. Термин входит в общую лексическую систему языка, но лишь через посредство конкретной терминологической системы» [3].
Юридическим терминам дается следующее определение - «слова (или сочетания слов), которые являются наименованиями определенных юридических понятий» [4, с. 21], в правоведении юридический термин определяется как «слово или словосочетание, которое употреблено в законодательстве, являясь обобщенным наименованием юридического понятия, имеющего точный и определенный смысл, и отличающееся смысловой однозначностью, функциональной устойчивостью» [5, с. 65].

Теперь рассмотрим понятие «метафора», в словаре [3] она определяется как «троп или механизм речи, состоящий в употреблении слова, обозначающего некоторый класс предметов, явлений и т. п., для характеризации или наименования объекта, входящего в другой класс, либо наименования другого класса объектов, аналогичного данному в каком-либо отношении. В широком смысле термин “метафора" применяется к любым видам употребления слов в непрямом значении».

Исходя из вышеизложенного, можно сказать, что понятия «термин» и «метафора» находятся на разных сторонах языковой структуры. Таким образом, метафора является многозначной, экспрессивной и образной, в то время как термин характеризуется конкретикой, однозначностью и стилистической нейтральностью. Несмотря на это, метафоризация является одним из продуктивных способов терминообразования. Как правило это связано со следующими факторами.

1. Носителю языка проще представить неизвестное через известное явление, так как информацию проще обработать с помощью уже имеющихся образов и понятий.

2. Благодаря использованию метафоры термин получает высокую степень мотивированности, что позволяет новой единице быстрее адаптироваться в системе языка.

3. Как правило, термины-метафоры не обладают многозначностью и экспрессивностью, но в то же время мотивированность термина позволяет более активно использовать новую единицу в различных отраслях науки.

В ходе системно-структурной обработки данных словарей были получены сведения о том, что процесс метафоризации является полноценным и функциональным способом терминообразования в сфере юриспруденции и права. Термины-метафоры представлены в различных отраслях права. Вот некоторые из них:

- финансовое право: bare trust (naked trust) (букв. голый траст) - пассивный траст, в котором доверительный управляющий не имеет никаких обязательств, кроме передачи доверительного имущества лицу, имеющему на него право, по просьбе послед- 
него. Это произойдет, когда бенефициар достигнет совершеннолетия и не будет иметь инвалидности, а опекун не будет нести никаких обязанностей в отношении имущества;

\section{- трудовое право:}

1) beauty competition (букв. конкурс красоты) метод, используемый работодателем, предусматривающий заключение единого профсоюзного соглашения, в котором ряду профсоюзов предлагается представить предложения о заключении коллективных договоров в рамках учреждения. После рассмотрения предложений компания принимает решение о признании союза, который наилучшим образом соответствует ее критериям;

2) garden leave clause (букв. командировка в сад) - описывает практику, при которой работник, уходящий с работы, уволившись или иным образом прекратив свою трудовую деятельность, получает указание держаться подальше от работы в течение периода уведомления, оставаясь при этом на зарплате. Это используется, когда должность сотрудника больше не требуется в течение периода уведомления. Чтобы сохранить положение о неконкурентности работника, эта практика часто используется для предотвращения того, чтобы работник не брал с собой актуальную (и, возможно, конфиденциальную) информацию, когда он покидает своего нынешнего работодателя, особенно когда он очень вероятно уходит, чтобы присоединиться к конкуренту. Этот термин широко используется в банковской и другой финансовой сфере в Великобритании, Австралии и Новой Зеландии. Иногда эта практика используется для того, чтобы избежать вялой работы или саботажа со стороны незаинтересованного или недовольного сотрудника;

- брачное право: clean break (букв. чистый разрыв) - соглашение о полном разрыве, заключенное между разведенной парой в отношении того, как они будут делить свои активы, включая имущество, сбережения и другие финансы. Соглашение позволяет паре заключить окончательное соглашение в отношении финансов, чтобы получить полную финансовую независимость друг от друга. После заключения соглашения ни один из супругов не будет иметь права предъявлять друг другу какие-либо дополнительные финансовые претензии. Для пар, у которых есть дети, порядок полного разрыва не может быть организован, пока выплачивается содержание ребенка. Тем не менее адвокат поможет организовать полный разрыв во всех других финансовых отношениях между супругами;

- имущественное право: mere equity (букв. простая справедливость) - право, затрагивающее имущество, которое менее существенно, чем «еquitable right» или «legal right» (законное право): оно не затрагивает никого, кроме сторон в сделке, где оно содержится, примером может служить право на исправление (to rectify) документа;

- международное право: soft law (букв. нежное право) - руководящие принципы поведения, такие как те, которые предусмотрены еще не вступившими в силу договорами, резолюциями Организации Объединенных Наций или международными конференциями, которые сами по себе не являются обязательными, но представляют собой нечто большее, чем просто заявления о политических устремлениях (они попадают в правовую/политическую неопределенность между этими двумя государствами);

- коммерческое право: act of honor (букв. закон чести) - сделка, зафиксированная в документе, подготовленном нотариусом, свидетельствующая о согласии третьего лица принять в кредит одной или нескольких сторон вексель, который был опротестован.

Частеречный анализ показывает, что большую часть метафор составляют существительные и прилагательные, едичные случаи образования терминов с помощью глаголов. Если рассматривать примеры грамматических конструкций терминов-метафор, то в основном это конструкции следующего вида:

1) прил. + сущ. golden handshake (букв. золотое рукопожатие) - выплата, обычно очень крупная, производимая директору или другому руководителю высшего звена, который вынужден уйти на пенсию до истечения срока действия трудового договора (например, из-за поглощения или слияния) в качестве компенсации за потерю должности. Это делается, когда договор не допускает оплаты вместо уведомления. Первые 30000 фунтов часто не облагаются налогом;

2) сущ. + предл. + сущ. fruits of the poisonous tree (букв. плоды отравленного дерева) - доктрина, которая расширяет исключительное правило, чтобы сделать доказательства неприемлемыми в суде, если они были получены из доказательств, которые были получены незаконно. Как подсказывает метафора, если очевидное «дерево» испорчено, то и его «плод» тоже. Доктрина была создана в 1920 г. решением суда в деле Silverthorne Lumber Со. против Соединенных Штатов, и фраза «плод отравленного дерева» была придумана судьей Франкфуртером в его заключительной речи 1939 г. в деле Нардон против Соединенных Штатов;

3) сущ. + сущ. ship's husband (букв. корабельный муж) - генеральный агент судовладельцев по ведению дел, связанных с судном;

4) прил. + сущ. + сущ. trade dress infringement (букв. контрафакция торгового платья) - происходит, когда дизайн или упаковка одного продукта копируют или имитируют дизайн другого продукта до такой степени, что существует вероятность путаницы в сознании покупающей публики. 
Особого внимания заслуживают термины-метафоры, которые включают в себя колоративные элементы. На текущий момент колоративная образность в терминологии изучена недостаточно хорошо, информация о терминах с цветокомпонентами представлена разрозренными фактами и отдельными статьями [6]. Колоростика показывает специфику восприятия окружающего мира какой-либо нацией посредством родного языка.

Колоративные образы разных народов отражают внутренний мир человека, его индивидуальность, а также самобытность. Цветосимволизм широко изучается многими науками, такими как, например, психология.

На материале английской юридической терминологии были выделены девять базовых цветов: красный (red), оранжевый (orange), желтый (yellow), зеленый (green), синий (blue), белый (white), черный (black), серый (gray), розовый (pink).

Стоит обратить внимание, что в примерах семантика цвета может иметь как прямое, так и переносное значение, встречаются случаи символического употребления.

Рассмотрим юридические термины, которые содержат цветокомпоненты:

red herring (букв. красная селедка) - не относящийся к делу юридический или фактический вопрос, отвлекающий маневр;

red-light abatement laws (букв.законы о борьбе с красными фонарями) - постановление или закон, направленные на ликвидацию и запрещение проституции;

Orange Book (относится к патентному праву) (букв. оранжевая книга) - перечень патентов на лекарства или лекарственные препараты, заявки на которые могут подаваться в Управление по контролю за продуктами питания и лекарственными средствами;

Yellow Book (букв. желтая книга) - книга о правилах торговли акциями на Лондонской фондовой бирже;

yellow-dog contract (букв. договор желтой собаки) - трудовой договор, запрещающий членство в профсоюзе;

Board of Green Cloth (букв. комитет зеленой ткани) - группа лиц, ответственных за управление персоналом королевской семьи, особенно в финансовых вопросах, таких как учет расходов и оплата труда служащих;

evergreen contract (букв. вечнозеленый контракт) - договор, который продлевается с одного срока на другой в отсутствие уведомления об обратном одной из сторон;

blue-ribbon jury (букв. присяжные синей ленты) присяжные заседатели, состоящие из присяжных заседателей, которые отбираются по их особым качествам, таким как высшее образование или специальная подготовка, иногда используются в сложных гражданских делах (обычно по соглашению сторон), а иногда и для суда присяжных (особенно при расследовании коррупционных преступлений);

blue law (букв. синий закон) - закон, регулирующий или запрещающий коммерческую деятельность по воскресеньям;

white-collar crime (букв. преступление белых воротничков) - ненасильственное преступление, мошенничество или мошенничество в коммерческих вопросах, хищения, взяточничество и инсайдерская торговля;

whitehorse case (букв. дело белой лошади) - зарегистрированное дело с фактами, практически идентичными фактам данного дела, так что решение по зарегистрированному делу должно определять исход данного дела;

blacklist (букв. черный лист) - список, содержащий сведения о членах профсоюзов, и в частности сведения о профсоюзных активистах, составленный с целью использования внешними органами, обычно работодателями и их ассоциациями, в целях дискриминации в отношении найма и обращения с работниками;

Black Act (букв. черный закон) - английский статут, установление смертной казни за незаконное убийство или увечье животных;

graymail (букв. серая почта) - угроза обвиняемого раскрыть секретную информацию во время судебного разбирательства в надежде заставить правительство отказаться от уголовного обвинения;

gray market (букв. серый рынок) - рынок, на котором продавец использует законные, но иногда неэтичные методы, чтобы избежать дистрибьюторской цепочки производителя и тем самым продать товары (особенно импортные товары) по ценам ниже, чем те, которые предусмотрены производителем;

pink sheet (букв. розовый лист) - ежедневное издание со списком внебиржевых акций с их ценами;

pink slip (букв.розовое скольжение) - уведомление о прекращении трудового договора, выданное работнику работодателем.

Таким образом, цветовая образность правовых терминов в английском языке говорит о том, что связь цвета и внутреннего мира человека не является однозначной и линейной и требует дополнительного и тщательного изучения перед переводом на русский язык. Метафоризация способствует развитию различных терминосистем, а также образованию новых активно употребляемых терминов. 


\section{Заключение}

Подводя итоги, можно сказать, что метафоризация является достаточно продуктивным способом в процессе терминообразования, но не самым частотным способом терминообразования. Необходимо помнить о том, что язык правовой терминологии не терпит многозначности, а напротив, в текстах данного типа должна быть смысловая определенность и однозначность толкования.

Также следует отметить, что метафоризация правового термина случается в неофициальном толковании права. При официальном толковании степень метафоризации лексических единиц довольна низка.

\section{ЛИТЕРАТУРА}

1. Oxford dictionary of Law / ed. by E. A. Martin. Oxford : Oxford University press, 2003. 552 p.

2. Black's Law dictionary / ed. by B. A. Garner. New York: Thomson Reuters business, 2009. 1920 p.

3. Лингвистический энциклопедический словарь / под ред. В. Н. Ярцевой. М. : Советская энциклопедия, $1990.688 \mathrm{c}$

4. Ткачева Л. Б. Основные закономерности английской терминологии. Томск : ТГУ, 1986. 198 с.

Воронежский институт Министерства внутренних дел Российской Федераџии

Жилина И. А., кандидат филологических наук, доиент кафедры иностранных языков

E-mail: 5irinater12@gmail.com

Панкратова М. Е., кандидат филологических наук, доиент кафедры иностранных языков

E-mail: marina.e.pankratova@gmail.com

Поступила в редакиию 4 марта 2020 г.

Принята к публикации 15 июня 2020 г.

\section{Для цитирования:}

Жилина И. А., Панкратова М. Е. Процесс метафоризации в англоязычной юридической терминологии // Вестник Воронежского государственного университета. Серия: Лингвистика и межкультурная коммуникация. 2020. № 3. C. 89-93. DOI: https://doi.org/10.17308/lic. $2020.3 / 2937$
5. Язык закона / под ред. А. С. Пиголкина. М. : Юрид. лит., 1990. 192 с.

6. Росянова T. С. Колоративная экономическая терминология в современном английском языке // Управленческое консультирование. 2016. № 3 (87). С. 121-128.

\section{REFERENCES}

1. Oxford dictionary of Law. Ed. by E. A. Martin. Oxford: Oxford University press, 2003.

2. Black's Law dictionary. Ed. by B. A. Garner. New York: Thomson Reuters business, 2009

3. Lingvisticheskij enciklopedicheskij slovar' [Linguistic encyclopedic dictionary]. Ed. by V. N. Yartseva. Moscow: Soviet encyclopedia, 1990.

4. Tkacheva L. B. Osnovnye zakonomernosti anglijskoj terminologii [Basic laws of English terminology]. Tomsk: Tomsk State University, 1987.

5. Jazyk zakona [Language of the law]. Edited by A. S. Pigolkin. Moscow: Yurid. lit., 1990.

6. Rosyanova T. S. Kolorativnaya ekonomicheskaya terminologiya $\mathrm{v}$ sovremennom anglijskom yazyke [Color-Symbolism in English Economic Terminology] in Upravlencheskoe konsul'tirovanie. 2016. No. 3 (87). Pp. 121-128.

Voronezh Institute of the Ministry of Internal Affairs of the Russian Federation

Zhilina I. A., Candidate of Philology, Associate Professor of the Foreign Languages Department

E-mail:5irinater12@gmail.com

Pankratova M. E., Candidate of Philology, Associate Professor of the Foreign Languages Department

E-mail: marina.e.pankratova@gmail.com

Received: 4 March 2020

Accepted: 15 June 2020

\section{For citation:}

Zhilina I. A., Pankratova M. E. The process of metaphorization in English legal terminology. Proceedings of Voronezh State University. Series: Linguistics and Intercultural Communication. 2020. No. 3. Pp. 89-93. DOI: https:// doi.org/10.17308/lic.2020.3/2937 